UNITED NATIONS CONFERENCE ON TRADE AND DEVELOPMENT FOR CROSS-BORDER BANKING

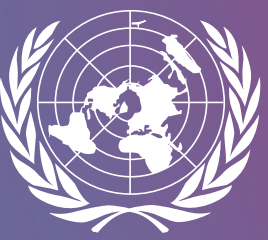

UNITED NATIONS 



\title{
MACROPRUDENTIAL REGULATION: POTENTIAL IMPLICATIONS FOR RULES FOR CROSS-BORDER BANKING
}

\author{
Andrew Cornford
}

No. 216

April 2014

Acknowledgement: The author is grateful for comments from an anonymous referee and from the editor of the Discussion Paper series. 
The opinions expressed in this paper are those of the author and are not to be taken as the official views of the UNCTAD secretariat or its member States. The designations and terminology employed are also those of the author.

UNCTAD Discussion Papers are read anonymously by at least one referee, whose comments are taken into account before publication.

Comments on this paper are invited and may be addressed to the author, c/o the Publications Assistant, Macroeconomic and Development Policies Branch (MDPB), Division on Globalization and Development Strategies (DGDS), United Nations Conference on Trade and Development (UNCTAD), Palais des Nations, CH-1211 Geneva 10, Switzerland; e-mail: gdsinfo@unctad.org; fax no: +41 22917 0274. Copies of Discussion Papers may also be obtained from this address.

UNCTAD Discussion Papers are available on the UNCTAD website at http://www.unctad.org. 
Contents

Abstract

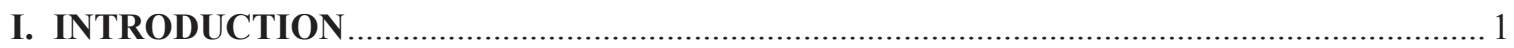

II. CAPITAL CONTROLS, PRUDENTIAL REGULATION AND GATS RULES ........................ 2

III. DISCUSSION OF MACROPRUDENTIAL MEASURES AND GATS RULES IN THE WTO

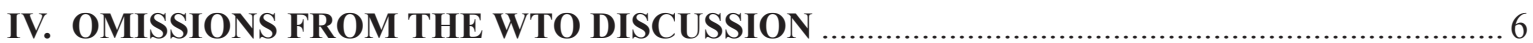

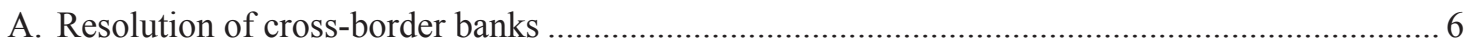

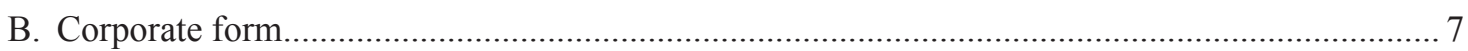

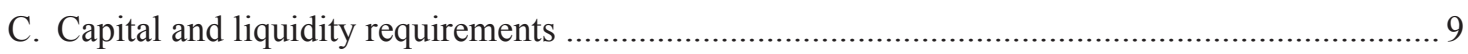

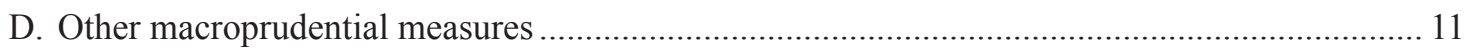

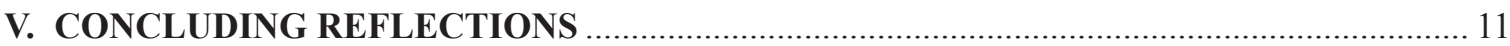

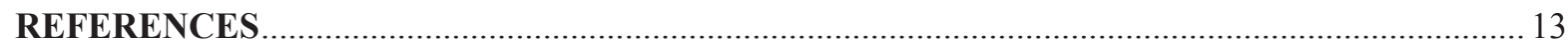





\title{
MACROPRUDENTIAL REGULATION: POTENTIAL IMPLICATIONS FOR RULES FOR CROSS-BORDER BANKING
}

\author{
Andrew Cornford \\ Observatoire de la Finance, Geneva
}

\begin{abstract}
In the post-crisis agenda of reform of financial regulation, macroprudential regulation has been assigned a central role. Some of the measures of this agenda involve restrictions on cross-border financial flows and discriminatory restrictions targeting particular financial institutions and activities. Others target corporate form and the relations between the constituent parts of banking groups. Many of the measures implemented or proposed as part of the reform agenda may be inconsistent with the WTO General Agreement on Trade in Services (GATS) and with other bilateral and regional agreements on trade and investment in banking services. As a result both sets of rules may eventually require revision.
\end{abstract}

\section{INTRODUCTION}

In the post-crisis agenda of the reform of financial regulation macroprudential policy has been assigned central importance. Macroprudential policy is directed at the financial system as a whole rather than individual financial institutions. In the words of a recent report of the Group of Thirty, "Macroprudential policy aims to enhance the resilience of the financial system and to dampen systemic risks that arise and propagate internally in the financial system through the interconnectedness of institutions by virtue of common exposure to shocks and the tendency of financial institutions to act in procyclical ways that magnify the extremes of the financial cycle" (Group of Thirty, 2010: 21).

So defined, the scope of macroprudential policy covers not only banking crises but also macroeconomic or sovereign crises whose impact extends to the banking sector. The role now attributed to macroprudential policy is having major effects on the landscape of regulatory measures included in both national and international reform agendas. Systemic risk is a longstanding concern of financial regulation and supervision, and is part of the rationale for lender-of-last-resort financing for banks. But the attention given to macroprudential policies, i.e. policies targeting systemic risk, since the start of the current crisis is leading to the development of a more unified and better articulated framework for measures for this purpose.

Much of the discussion which follows concerns the rules of the General Agreement on Trade in services (GATS) in the World Trade Organisation (WTO) for international trade in banking services, a term which covers not only cross-border transactions in banking services but also the commercial presence of 
foreign banking firms. The reason for this approach to discussion of the implications of macroprudential regulation is that the GATS constitutes a single coherent set of rules that highlights major dimensions of the relationship between banking regulation and cross-border banking transactions which are also relevant for other international agreements. ${ }^{1}$ Thus problems potentially posed by macroprudential regulation to GATS rules have implications also for bilateral and regional trade and investment agreements which include provisions for capital movements and cross-border transactions in banking services with often more far-reaching obligations as to liberalisation than the GATS. For such agreements, as for the GATS, there is a question as to whether they provide adequate policy space for the prudential regulation of banking transactions currently being developed and introduced.

\section{CAPITAL CONTROLS, PRUDENTIAL REGULATION AND GATS RULES}

Since the completion in 1997 of the negotiation of commitments on international trade in financial services under the GATS several organisations and commentators have raised questions as to what prudential measures are covered by the Prudential Defence Measure (PDM) of the Annex on Financial Services of the GATS, and as to whether the PDM together with other GATS rules provide adequate scope for the use of capital controls.

Under the section on domestic regulation of the Annex, according to the PDM, "Notwithstanding any other provisions of the Agreement, a Member shall not be prevented from taking measures for prudential reasons, including for the protection of investors, depositors, policy holders or persons to whom a fiduciary duty is owed by a financial service supplier, or to ensure the integrity of the financial system." However, the latitude thus provided for regulatory measures is followed by an anti-circumvention qualification: "Where such measures do not conform with the provisions of the Agreement, they shall not be used as a means of avoiding the Member's commitments or obligations under the Agreement".

The inclusion of the PDM in the GATS was the outcome of contentious negotiations during which several developing countries sought substantial freedom from possible challenge under the GATS for prudential measures. The qualified acceptance in the PDM of countries' right to take prudential measures reflected also the conflict with the dominant view of the developed countries participating in the negotiations regarding the benefits in comparison with the costs of the liberalisation of international trade in financial services, that is to say of both cross-border financial transactions and of restrictions on the commercial presence of foreign financial institutions.

The practical scope of the PDM has been the subject of much disagreement. The definitions of the terms, "prudential" and "fiduciary", were left open. This lacuna seemed important primarily with respect to prudential measures. As the Asian financial crisis unfolded during the same period as the completion of the WTO negotiation of commitments on international trade in financial services at the end of 1997, the question arose whether the PDM covered only measures taken to protect financial sectors from collapse during and in the immediate aftermath of the banking crises or whether it also covered prudential reforms undertaken as part of the longer-term restructuring of countries' banks and regulatory regimes which followed. This question has re-emerged with a vengeance in the context of the massive, long-term restructuring of prudential regimes in response to the fault lines - primarily in the regimes of developed countries - revealed during the current financial crisis which began in 2007.

\footnotetext{
${ }^{1}$ I have discussed some questions concerning the protection accorded by the Annex on Financial Services of the GATS to prudential measures more generally in other recent papers (for example, Cornford, 2012; Cornford, 2012/2013). Except for the question of the protection afforded to controls over cross-border capital movements the principal focus of these papers is microprudential measures, i.e. measures directed at controlling the risks of individual firms with usually only an incidental impact on systemic risks within the financial sector.
} 
A second question concerned relations between prudential measures, banking crises, and capital controls. Although typically imposed in response to balance-of-payments problems, capital controls will generally have effects not only on the country's macroeconomy but also on its banks owing to the effects of capital inflows and outflows on both the scale and currency denomination of assets and liabilities in banks' balance sheets. In a report of 2000 a working group on capital flows of the Financial Stability Forum, the predecessor body of the Financial Stability Board (FSB), accepted the idea that there are circumstances in which the introduction of capital controls can be justified as a prudential measure both for macroeconomic reasons (for example, unwanted movements of the exchange rate and consequent complications of domestic monetary policy) and "to reinforce or complement prudential requirements on financial institutions" (Financial Stability Forum, 2000: 34-37).

The connection drawn here between the prudential and the macroeconomic objectives of capital controls would appear to place such controls in the category of macroprudential measures, although "macroprudential" was not yet a standard term. The working group of the Financial Stability Forum limited its imprimatur to controls over capital inflows. Controls over capital outflows were excluded, not altogether convincingly, on the grounds that these "should be thought of more as an element of crisis management and, as such, are beyond the scope of this paper".

Since the beginning of the current crisis the official view of the relation between macroprudential measures and capital controls has been clarified and extended.

For example, in a recent document on capital flow management measures (CFMs, the current IMF term for capital controls) and macroprudential measures (MPMs) the IMF draws a distinction between the two on the basis of their primary objectives: "CFMs are measures ... that are designed to limit capital flows, while MPMs are prudential tools that are primarily designed to limit systemic financial risk and maintain financial system stability". However the IMF also acknowledges that there are situations where CFMs and MPMs overlap: "To the extent that capital flows are the source of systemic financial risks [which they have been in several financial crises], the tools used to address those risks can be seen as both CFMs and MPMs. An example could be when capital inflows into the banking sector contribute to a boom in domestic credit and asset prices. A restriction on banks' foreign borrowing ... would aim to limit capital inflows, slow down domestic credit and asset price increases, and reduce banks' liquidity and exchange rate risks. In such cases the measures ... would be considered both CFMs and MPMs" (IMF, 2012: 21).

The IMF now accepts a temporary role for CFMs on capital outflows for countries which face domestic or external shocks which are large relative to the ability of either macroeconomic adjustment or financial sector policies on their own to handle. "When a crisis is considered imminent, CFMs may be desirable if they can help prevent a full-blown crisis" (IMF, 2012: 25). Although in the IMF's view "the outflow CFMs should always be part of a broader policy package that also includes macroeconomic, financial sector, and structural adjustment to address the fundamental causes of the crisis" [i.e. part of a policy package generally including a number of macroprudential measures], the IMF avoids the use of the term "macroprudential" in the context of outflow CFMs. Such fine distinctions are likely to be lost outside the institutional setting of IMF discussions with the result that in many situations, and for many people, the terms MPM and CFM are likely to be used interchangeably.

How far are these changing views concerning capital controls and macroprudential regulation accommodated by the rules of the GATS?

Restrictions on capital movements are covered in Articles XI and XII and in a footnote of Article XVI of the GATS. Article XI.2 prohibits restrictions on capital transactions related to a country's commitments as to market access and national treatment. However, according to Article XII, this prohibition may be overridden by a country's need to undertake actions to safeguard the balance of payments in the event of serious external financial difficulties. Consultations concerning the need to take such actions are to be based on statistical and other empirical findings of the IMF and on the Fund's assessment of the 
country's external financial position. The footnote of Article XVI, which covers the rules for the granting of market access to services suppliers, specifies that capital movements integrally related to commitments regarding cross-border supply of banking services must be allowed, as must transfers of capital related to commitments regarding supply of services through a commercial presence.

In the context of macroprudential policy capital controls may be necessary not only in classical balance of payments crises where the policy challenge is the exhaustion of a country's foreign-exchange reserves but also for handling difficulties caused by excessive upwards pressures on exchange rates due to capital inflows (as acknowledged in the IMF document quoted earlier). A number of emerging-market countries have experienced such pressures during the current crisis.

Capital controls in response to such pressures have a history which also includes their deployment by developed countries during periods of currency turbulence in the 1960s and 1970s. Capital controls during that period included the requirement of approval, not always granted, for sales to non-residents of German money-market paper and fixed-interest securities issued by German entities with less than four years to maturity; bans on interest on balances held for non-residents at German and Dutch commercial banks, the requirement that Swiss banks charge commissions equivalent to negative interest on deposits owned by non-residents; and discriminatory reserve requirements imposed by Germany, Switzerland and Japan on bank liabilities to foreigners (Mills, 1976: 180-211).

The thinking behind Article XII of the GATS concerns classical balance-of-payments crises. Thus according to Article XII.1 "in the event of serious balance-of-payments and external financial difficulties or threat thereof" restrictions on [cross-border] trade in services are permitted. However, the statement which follows suggests that the Article was intended to be directed at balance-of-payments difficulties associated with capital outflows: "It is recognized that particular pressures on the balance of payments of a Member in the process of economic development or economic transition may necessitate the use of restrictions, to ensure, inter alia, the maintenance of a level of financial reserves adequate for the implementation of its programme of economic development or economic transition".

Only case law developed through dispute settlement will determine whether the Article XII can justify the deployment of capital controls in the face of difficulties caused by excessive capital inflows as well as by excessive outflows. However, the increased official acceptance of the overlap between prudential objectives and the objectives of the macroeconomic management of balance-of-payments crises would appear to reinforce the scope which GATS rules provide countries for the use of capital controls. Thus, failing justification under Article XII, the implication of the changed official view is that justification of such controls under the PDM would now be more likely to be effective (although uncertainty due to the anti-circumvention provision which follows the PDM would still remain).

These arguments also have implications for bilateral and regional agreements on trade and investment. If the combination of Article XII of the GATS and the PDM of the Annex on Financial Services does provide scope for the acceptance of capital controls (as suggested above), then in a world where volatile capital movements can pose serious problems for both macroeconomic and prudential policy analogous scope for the deployment of such controls should surely be included in the rules of such agreements. 


\section{DISCUSSION OF MACROPRUDENTIAL MEASURES AND GATS RULES IN THE WTO}

Uncertainty as to the precise scope of the protection for prudential measures afforded by the PDM has led to much debate to which commentators under United Nations auspices, academic experts and non-governmental organisations have contributed (Cornford, 2012). Such uncertainty also figured in a communication of Barbados to the WTO Committee on Trade in Financial Services (WTO, 2011).

The initiative for the first dedicated discussion of macroprudential issues in the WTO came from Ecuador in early 2012. Consultations with other member countries led Ecuador to conclude that there was no consensus on preparing a legal interpretation of the GATS rules in relation to macroprudential regulation or on analysis in the WTO of specific macroprudential measures. Such alternatives, many countries believed, risked narrowing the scope of the existing rules to the possible detriment of WTO members. Ecuador's revised proposal for a free-ranging discussion of the experience of member countries in the implementation of macroprudential policies was subsequently accepted.

The discussion took place at a meeting of the WTO Committee on Financial Services in March 2013. It was led by Ecuador which described the financial crisis experienced by the country in 1998. The fiscal cost of the bank bail-outs amounted to 30 per cent in a single year and 13 of the 15 banks which received government funds became insolvent. The economy was dollarized and an extensive programme of macroprudential regulation was introduced. This included a constitutional ban on bank bail-outs, the separation of commercial and investment banking, and the establishment of a liquidity fund to perform the functions of lender of last resort and of a fund for deposit insurance. The impression left by Ecuador was that, in view of the inflexibility introduced into its financial system by dollarization and by the ban on bail-outs, the country was conscious of its need for maximum flexibility regarding the other instruments of financial policy in a possible future crisis, including recourse to capital controls.

Two of the countries which explicitly addressed the issue of measures permitted under the PDM were Australia and Canada, both of which expressed the belief that the PDM provided them with the required flexibility for effective prudential regulation. A third was the Republic of Korea (see below).

Other participants in the debate such as Argentina and Brazil expressed concern over volatility of international capital movements since the outbreak of the financial crisis and the resulting need for according countries policy space regarding the use of capital controls. Moreover there was widespread agreement during the debate concerning the need for coordination between the WTO and other bodies responsible for the setting and implementation of financial standards such as the FSB, the Basel Committee on Banking Supervision (BCBS), and the IMF.

An interesting but only briefly fleshed out intervention was made by the Republic of Korea which saw the need for a distinction between ex-ante measures designed to prevent a crisis and ex-post measures designed to address problems due to the outbreak of crisis. The country accepted that the PDM provided sufficiently flexibility regarding ex-ante macroprudential measures. However, it also believed that further discussion was needed on whether the PDM provided sufficient flexibility regarding ex-post macroprudential measures - in particular regarding the issue of whether the measures taken involved the subsidisation of government-owned banks.

The reference here sounds as if it was inspired by the country's concern as to whether the sort of measures it took in response to its banking crisis beginning in late 1997 would be covered by the PDM. The restructuring programme of the Republic of Korea included mergers, fresh equity injections, enforced redundancies, management reform, and fiscal support through Korea Asset Management Corporation (KAMCO) and Korea Deposit Insurance Corporation (KDIC) which amounted to US\$50 million. During the programme many of the financial institutions involved, owing to their insolvency, were effectively government-owned (Golin, 2000: 489-494). The measures taken by the Republic of Korea could be categorised as ex-post macroprudential. 


\section{OMISSIONS FROM THE WTO DISCUSSION}

Missing from the exchanges at the WTO was detailed discussion not only of the relation of GATS rules to capital controls but also of several other issues currently being addressed as part of the agenda of macroprudential regulation. The sequel here takes up the implications for the GATS - and by extension for bilateral and regional trade and investment agreements - of two categories of regulation directed at the corporate structure of banks as well as of several measures directed at both banking transactions and the assets and liabilities of cross-border banks.

\section{A. Resolution of cross-border banks}

The development of rules for handling insolvencies of banks with cross-border operations is a long-standing item of the agenda of international financial reform. Progress has been slow owing to the difficulty of achieving agreement concerning the required harmonization of significantly different existing national laws and definitions and concerning the distribution of the costs of the insolvencies among the countries in which firms affected by the insolvency have a commercial presence. Development of rules for the cross-border insolvencies of financial firms is closely linked to the regulation of financial firms too big to fail (TBTF), i.e. financial firms whose failure is a source of systemic risk. Classification of a financial firm as TBTF reflects a view of the systemic risk posed by the failure of such a firm, thus making such a failure an issue for macroprudential policy.

Work on cross-border bank insolvencies by the Basel Committee on Banking Supervision (BCBS) and the FSB was given a fillip by experience of such insolvencies of large cross-border banks during the financial crisis. However, although issues connected to bank insolvencies, have been extensively ventilated as part of this work, international agreement is still limited to arrangements designed to smooth resolution when more than one jurisdiction is involved, and does not include an agreed set of model procedures.

Thus the key document of the FSB on resolution regimes (FSB, 2011: 13-15 and Annex I) includes the following principles (home jurisdiction being that of the parent bank of a group of cross border banking entities):

- The mandate of the resolution authority should empower and encourage the resolution authority to achieve a cooperative solution with foreign resolution authorities;

- Regulation should not include provisions that trigger automatic action in response to official intervention or the initiation of resolution or insolvency proceedings in another jurisdiction;

- The resolution authority should have resolution powers over local branches of foreign firms and the capacity to use its powers to support a resolution carried out by a foreign home authority or to take measures on its own initiative where the home jurisdiction is not taking action or is acting in a manner that does not take sufficient account of the need to preserve the local jurisdiction's financial stability;

- Jurisdictions should provide for transparent and expedited processes to give effect to foreign resolution measures, either by way of a mutual recognition process or by taking measures under the domestic resolution regime that support and are consistent with the resolution measures taken by the foreign home resolution authority. Such recognition or support measures would enable a foreign home resolution authority to gain rapid control over the firm or the assets of the firm that are located in the host jurisdiction in cases where the firm is being resolved under the laws of the foreign home jurisdiction;

- The resolution authority should have the capacity, subject to adequate confidentiality requirements, to share information pertaining to the banking group as a whole or to individual subsidiaries and branches with the relevant foreign authorities where such sharing is necessary for the implementation of a coordinated resolution. 
In the case of global systemically important financial institutions (G-SIFIs) there are additional provisions concerning the establishment of official Crisis Management Groups with the objective of enhancing preparedness for and facilitating the management and resolution of cross-border crises affecting the firms involved. Key elements of such preparedness are also specified.

But these principles fall short of agreement on the way in which losses should be distributed between different entities in a cross-border banking group - whether, as noted by Paul Tucker, the Deputy Governor for Financial Stability of the Bank of England, to use the Single-Point-Entry strategy, under which losses flow to the group's top company, or the Multiple-Point-of Entry strategy, under which the group is broken up into constituent parts, for the purpose of resolution (which implies that the host authority of a subsidiary identified for separation must ensure that it has the required capital and operational independence to make possible resolution by the authority) (Tucker, 2013).

In the same speech Tucker notes that the development of international policy on the resolution of insolvent banks is exposing vagueness as to precise requirements of adequate banking regulation and supervision in key international agreements negotiated in the BCBS as they apply to the parent bank and other entities of a cross-border banking group. The agreements in question are the Concordat which establishes the division of labour between home and host authorities, Core Principles for Effective Banking Supervision which enunciate minimum standards for prudential supervision, and the various versions of the Basel Capital Accord. The emphasis in these agreements is on consolidated supervision of the group, accompanied by solo supervision of local entities in different jurisdictions. Overriding supervisory responsibility is attributed to the supervisor of the parent bank but without any guarantee that the capital of the group as a whole is distributed in such a way that each constituent entity is adequately capitalised. The distribution of loss-absorbing capital becomes particularly important when cross-border banks face insolvency.

\section{B. Corporate form}

Enhanced consciousness of this ambiguity and of the inadequate levels of capital at some major international banks during the current crisis (despite apparent conformity with the levels required by the Basel Capital Accords) is leading to a widespread re-examination among banking regulators of the respective merits of the subsidiary and branch forms for cross-border entities.

A recent proposal of the Federal Reserve Board in the United States announced in December 2012 appears to reflect such a re-examination in the context of addressing the risks associated with the increased complexity, interconnectedness and concentration of the United States operations of foreign banking organisations. The proposal is as follows:

- A foreign banking organisation with both US\$50 billion or more in global consolidated assets and United States subsidiaries with at least US\$10 billion in total assets would be required to organize its United States subsidiaries under a single United States Intermediate Holding Company (IHC), which would facilitate the consistent regulation and supervision of the bank's United States operations and, if necessary, the resolution of these operations in the event of failure;

- IHCs would be subject to the same risk-based and leverage capital standards as those applicable to United States bank holding companies. This would help to bolster the consolidated capital positions of the IHCs and to promote a level competitive playing field among banks operating in the United States;

- Foreign banks with combined United States assets of at least US\$50 billion would be required to meet enhanced liquidity risk-management standards, conduct liquidity stress tests, and hold a 30-day liquidity buffer of highly liquid assets.

This proposal is unlikely to be inconsistent with the WTO commitments of the United States. However, the proposal will impose additional costs on some foreign banks with an existing presence in the United States. But, more interestingly, the United States proposal is consistent with what appears to be part of a 
more general trend in many countries favouring subsidiarisation for foreign banks, that is to say policies which grant foreign banks access to the national market primarily or exclusively in the form of subsidiaries and which may also entail pressure on foreign institutions to transform existing branches into subsidiaries.

Arguments pertinent to subsidiarisation not only generally but also in the context of procedures for the resolution of cross-border banks were stated by Duvvuri Subbarao, then Governor of the Reserve Bank of India (RBI), in a speech to the Indian Banks' Association as follows: "First, managerial decisions in subsidiaries are mainly driven by local economic decisions. Second, there is a clear delineation of the capital of the domestic bank from its parent bank, which protects the interests of domestic depositors ... Finally, local incorporation affords greater leverage to host-country authorities than does a branch operation to ring-fence the operations of the bank" (quoted in Mehon, 2011: 66).

Considerations such as these no doubt explain the place of wholly owned subsidiaries in the policy recently announced by the RBI under which a larger role will be accorded to foreign banks in India but the granting of "near national treatment" will be linked to the condition of local incorporation. Existing foreign banks, especially those which are systemically important, will be encouraged to adopt local incorporation (Bandyopadhyay, 2013).

In its announcement the RBI linked this new policy to current international discussions of whether the resolution process for global financial institutions should be driven at the level of supervision in the institution's parent country or in its host country: "banks with complex structures, banks which do not provide adequate disclosure in their home jurisdiction, and banks from jurisdictions giving a preferential claim to depositors of home country in a winding up proceedings" would be given access to the Indian market only in the form of a wholly owned subsidiary (Global Risk Regulator, 2013: 17).

The question of banks' corporate form has also been raised in other contexts under the reform agenda. For example, the new international regulatory regime will have to accommodate reforms in the United States, the United Kingdom, and EU countries designed to achieve the legal separation of many of the activities of retail or traditional commercial banking, on the one hand, and of investment banking, on the other. The three main initiatives or proposals for this purpose are the Volcker Rule in the United States, the proposals of the Vickers Report in the United Kingdom in the United Kingdom, and the Likanen Report of the High-level Expert Group on reforming the structure of the EU banking sector (Gambacorta and van Rixtel, 2013: Annex A).

The Volcker Rule is included in the Dodd-Frank Wall Street Reform and Consumer Protection Act of 2010. With limited exceptions it prohibits deposit-funded, licensed commercial banks in the United Sates, foreign banks or bank holding companies with a United States branch or subsidiary, and affiliates of the above institutions from engaging in proprietary trading and investing in or sponsoring hedge funds and private equity funds. The prohibition on proprietary trading, which applies to transactions as a principal in securities, futures, forwards, or other derivatives, has a number of exemptions and the definition of the Rule's coverage for the purpose of regulations has proved complex and controversial, illustrating the difficulties of framing for modern financial markets regulations which distinguish between proprietary and non-proprietary trading and the resulting exposures of a bank.

Under the proposals of the Vickers Commission (embodied in the Banking Reform Act which became law in December 2013) banking groups headquartered in the United Kingdom would be required to "ringfence" banking services whose temporary interruption would have a significant, unfavourable impact on the domestic economy, in particular households and SMEs. Within its group the ring-fenced bank would be a separate legal entity meeting capital and liquidity requirements on a standalone basis and subject to special, higher capital requirements. Certain financial services such as the taking of retail deposits and the provision of overdrafts to individuals and SMEs would be provided only by ring-fenced entities. Services excluded from ring-fenced banks include those which impede resolution or increase the bank's exposures to shocks from financial markets. 
Where the Vickers Commission ring-fences domestic deposit-taking activities in a separately capitalised subsidiary, the Likanen Report would carve out proprietary trading and assets, liabilities and derivatives positions incurred in the process of market-making from other banking activities and, with limited exceptions for asset management, securities underwriting, and some hedging activities, assign them to a separate legal entity which would have its own capital but could be part of a holding-company also including deposit-taking subsidiaries.

In December 2012 the French Ministry of Finance presented a draft law which places certain investment banking and speculative activities in separate banking subsidiaries, while continuing to permit certain investment banking activities to be conducted from the deposit- taking subsidiary of the bank. In February 2013 the German government tabled a proposal broadly along the lines of the Likanen Report but applying only to banks with trading activities exceeding 100 billion Euros or 20 per cent of total assets.

While Dodd-Frank and the proposals of the Vickers Commission are now part of the law in the United States and the United Kingdom, the ultimate shape of rules elsewhere in EU countries designed to separate investment banking and speculative activities from traditional commercial banking is not yet clear. One outcome - and perhaps the most probable - would be a series of national solutions which take account of variations in the history of different countries' banking sectors and of their policy frameworks. These variations make unlikely international coordination of policy on this subject.

At the beginning of the 1990s when "measures which restrict or require specific types of legal entity or joint venture through which a service supplier may supply a service" were included amongst the limitations which countries are to include in their specific commitments according to Article XVI.2 of the GATS, there was a definite preference among the developed countries participating in the negotiation of the GATS in favour of according market access in the form of branches rather than subsidiaries since market access in this form was regarded as the most liberal of the alternatives.

This preference was not generally shared among developing-country participants. Curiously, more recently none the less there would appear to have been no public shift in the position of developed-countries in the WTO on corporate form. In spite of the regulatory initiatives regarding corporate form described above and indications of the more favourable view of subsidiarisation even among important developed countries, developing countries have continued to be subject to pressure at the WTO to drop all limitations on legal form in their commitments on market access. However, the trend in official opinion in favour of subsidiarisation suggests that, even where measures favouring subsidiarisation are not explicitly included in the limitations of a country's GATS commitments under Article XVI, they would now be more likely to be defensible under the PDM.

\section{Capital and liquidity requirements}

The rules of the Basel Accords Basel I, Basel II and Basel III - on capital requirements for credit, market and operational risk, and (in Basel III) on the control of liquidity risk - have been the subject of laborious negotiations amongst the member countries of the BCBS and of consultations with non-member countries. The intention of the drafters is that the implementation of the rules should be as far as possible globally uniform to avoid regulatory arbitrage between different jurisdictions.

However, one of the rules concerning capital requirements will inevitably be associated with variations at the level of both countries and individual banks. This is the countercyclical capital buffer, a macroprudential measure which is designed to prevent financial destabilisation due to large losses in the banking sector during an economic downturn following a period of excessive credit growth. National authorities will monitor credit growth and other indicators of potential system-wide risk and put in place countercyclical capital requirements of up to 2.5 per cent of risk-weighted assets when they view such requirements are warranted. The capital buffer will be released when the system-wide risks either crystallise or dissipate. 
The level of the countercyclical buffer may vary between jurisdictions and could thus be a potential cause of regulatory arbitrage or leakages via the substitution of cross-border credit provided by banks benefiting from lower buffers or by local branches of such banks. This is to be precluded under Basel III by mutual recognition of national countercyclical capital buffers. All of a bank's lending to a country cross-border or through a local branch - will be subject to the same countercyclical capital requirement up to the level of 2.5 of risk-weighted assets. Thus the countercyclical capital buffer of cross-border banks and banking groups will be a weighted average of the buffers for credit exposures which apply in each of the jurisdictions to which they have an exposure.

However, there are no such uniform rules for special sectoral capital and liquidity requirements which several jurisdictions (50 per cent of a sample of 46 covered in IMF, 2013: 50) have also imposed or are expected to impose in addition to the capital and liquidity requirements of the Basel Capital Accords.

Special sectoral capital requirements additional to those of Basel III may be applied to exposures such as mortgage lending, unsecured consumer credit or particular subcategories of such credit, lending on commercial property, and lending to other parts of the financial sector - of which the last one can be justified on the basis of the role played by intra-bank lending in precipitating and spreading the current financial crisis.

Special liquidity requirements which also supplement or adjust the rules of Basel III may target either banks' assets or their liabilities or funding. Increasing buffers of liquid assets during credit booms can provide banks with larger reserves which can be drawn down to meet margin calls or withdrawals of financing when the boom is followed by contraction. Increasing liquidity during booms can help to moderate cyclical increases in maturity mismatches by curbing credit expansion financed by volatile short-term funding. Supplementary reserve requirements for banks can also be deployed to restrain credit growth.

Included in its list of possible sectoral liquidity requirements by the Bank of England are adjustments to the classification of the liquidity of different instruments and sources of funding covered by the Liquidity Coverage Ratio (LCR) and the Net Stable Funding Ratio (NSFR) of Basel III. Under the LCR banks must have sufficient high-quality liquid assets to offset short-term cash flows, and under the NSFR banks must have minimum amounts of stable funding in relation to the liquidity profiles of their assets as well as potential liquidity needs arising from off-balance-sheet commitments. The objective of the Bank of England's proposal is to discourage reliance on particular funding sources and overexposures or underexposures to particular illiquid or liquid asset classes (Bank of England, 2011: 35).

Under liquidity requirements New Zealand has introduced a minimum Core Funding Ratio of 65 per cent. A Core Funding Ratio is a regulatory guideline which measures funding considered sustainable throughout the economic cycle (such as retail deposits and long-term wholesale funding) in relation to funding from all sources, which include shorter-term volatile deposits and money-market borrowing. The Republic of Korea has also introduced a series of measures designed to shift banks' funding structure away from the more volatile forms of funding. These include a cap on the loans to deposits ratio, ceilings on foreignexchange derivatives positions (which can be used to hedge short-term foreign-currency funding), and a tax on banks' non-core foreign currency liabilities.

Special sectoral capital requirements may be rendered less effective through various leakages: lending by local branches of foreign banks which are not subject to local regulation; cross-border lending by foreign banks which are not subject to local requirements on prudential capital; and cross-border lending by nonbank financial companies. Similarly leakages could impair the effectiveness of sectoral liquidity rules.

The Bank of England, which expects to apply special sectoral capital requirements to the exposures of banks, building societies and large investment firms to residential property, commercial property and to other parts of the financial sector, has acknowledged the potential risks to the measures' effectiveness from leakages. Thus it intends to monitor leakages to financial firms not covered by its requirements, 
including those which are cross-border. Action to stem the latter will be taken after consultations with other countries' authorities but presumably could entail restrictions on cross-border lending and discriminatory restrictions on the lending of foreign banks' branches.

\section{Other macroprudential measures}

Reduced effectiveness due to cross-border leakages may also apply to other macroprudential measures. For example, restrictions on the levels of Loan-to-Value Ratios and of Loan-to-Income Ratios in the case of mortgage lending could be evaded by cross-border lending by foreign banks, evasion which could be facilitated by the presence in the country of branches of such banks.

Likewise measures restricting lending for macroprudential reasons are also potentially vulnerable to crossborder leakages. For example, foreign banks could lend through wholesale financial markets to non-bank financial institutions not covered by the macroprudential restrictions, which in turn lend to non-financial entities. Non-financial corporations could borrow abroad from foreign banks and then lend within the corporate group to finance local operations. Attention has been drawn to both of these possibilities by the United Kingdom authorities (Group of Thirty, 2010: 37).

As in the case of special capital and liquidity requirements, such leakages through cross-border transactions may require efforts to improve policy coordination with the countries of the institutions which are the source of the leakages or, failing the success of such efforts, discriminatory restrictions on the institutions and transactions involved. Defence of such measures if challenged under the GATS rules would probably involve recourse to the PDM. Such a defence would exemplify the way in which the range of prudential measures has been extended from that in the minds of the original negotiators of the rules of the GATS at the beginning of the 1990s.

\section{CONCLUDING REFLECTIONS}

Banking crises typically start with events which trigger changes in sentiment towards a single institution or a group of similar institutions among other banks, the public or both. Their initial manifestation is illiquidity of the institution or institutions affected, i.e. the inability to meet financial obligations as they arise. Illiquidity may not initially be associated with insolvency, liabilities in excess of the value of assets, but generally becomes a threat to institutions' solvency as the value of their assets is threatened by the difficulties of realising them.

Banking crises are generally associated with both internal and external factors - poor quality of assets and in consequence fragile solvency, management incompetence, and the impact of deteriorating local or national market conditions on both the assets and liabilities of the banks affected. Thus macroprudential policies target banking structure, risk management and the features of crises once they have started.

Whilst systemic and non-systemic banking crises are easy to distinguish at a conceptual level, the distinction is more difficult to make in actual cases. Here one is confronted with the problem of the limits of transparency which chronically dogs analysis of, and thus forecasting based on, available financial data concerning banks such as those for capital, and thus for solvency, which can be - and in times of stress frequently are - manipulated. This problem is well characterised by the statement of two experienced bank credit analysts (Golin and Delhaise, 2013: 701), "what you see is not always what you get".

A consequence is that the character and range of banking interconnections which are capable of causing a systemic crisis can frequently only be identified ex post so that the policies to stem a systemic crisis and to deal with its consequences have to respond as it unfolds and its scope becomes clearer. This opacity implies that the authorities need flexibility regarding the policy response. 
The current crisis has highlighted the way in which systemic banking crises originating in one or more advanced countries can become global. As described above the policy response has included a wide-ranging agenda of prudential reforms, including what are now classified as macroprudential reforms. Some of the measures included in this agenda at national or international level involve restrictions on financial flows and discriminatory restrictions targeting particular cross-border financial institutions and activities. Others target banks' corporate structure and relations between the constituent units of banking groups.

Many of the measures implemented or proposed as part of the reform agenda, especially those classified under the heading of macroprudential which involve (sometimes discriminatory) controls over capital movements in situations where there is no balance-of-payments crisis, may be inconsistent with the GATS or not satisfactorily covered by its rules - unsurprisingly since these rules were drafted during the high noon of global financial liberalisation at the beginning of the 1990s. Such inconsistencies also characterise bilateral and regional trade and investment agreements in place or currently being negotiated despite the changes in the intellectual climate concerning banking regulation since the outbreak of the financial crisis, which now places greater emphasis on need for caution regarding rules concerning cross-border banking activities.

Revisions of provisions on cross-border banking and capital movements in existing bilateral and regional agreements on trade and investment in response to the rethinking of regulation under the head of macroprudential policy will be resisted by major developed countries which are parties to them, but under provisions common to most of these agreements this does not mean that revisions can be indefinitely excluded. One can also hope that the rethinking will have an impact on the treatment of cross-border banking and capital movements in future bilateral and regional agreements.

Member countries in the WTO for the time being have shown sensitivity to the rethinking now under way on cross-border banking and on capital movements. The current situation could be characterised as a mutually agreed armistice in the form of reluctance to test which macroprudential measures might and which might not be challenged as exceeding the latitude for prudential policy that is provided by the PDM of the Annex on Financial Services. The armistice seems likely to continue at least during the period of formulation of the global agenda of financial reform and perhaps well beyond. None the less the question of the scope which the GATS provides for macroprudential as well as microprudential regulation seems likely eventually to need revisiting. 


\section{REFERENCES}

Bandyopadhyay T (2013). New regime for foreign banks. The Livemint.Com. 7 November.

Bank of England (2011). Instruments of macroprudential policy. A Discussion Paper. December. Available at: http://www.bankofengland.co.uk/publications/Documents/other/financialstability/discussionpaper111220.pdf.

Cornford AJ (2012). Further Thoughts on the GATS Rules for Banking Services. Available at: http://www. networkideas.org/featart/feb2012/fa22_Andrew_Cornford.htm.

Cornford AJ (2012/2013). Notes on GATS rules for international trade in banking services for public forum at WTO, 26 September 2012. Financial Regulation International. December/January.

Financial Stability Board (FSB) (2011). Key Attributes of Effective Resolution Regimes for Financial Institutions. Basel, October.

Financial Stability Forum (2000). Report of the Working Group on Capital Flows. Basel, 5 April.

Gambacorta L and van Rixtel A (2013). Structural bank regulation initiatives: approaches and implications. BIS Working Paper No. 412, Basel, Bank for International Settlements. April.

Global Risk Regulator (2013). India opens to foreign bank subsidiaries. November.

Golin J (2000). The Bank Credit Analysis Handbook. Singapore, John Wiley and Sons (Asia).

Golin J and Delhaise P (2013). The Bank Credit Analysis Handbook. Second edition. Singapore, John Wiley and Sons (Singapore).

Group of Thirty (2010). Enhancing Stability and Resilience Macroprudential Policy, Tools, and Systems for the Future. Washington, DC, October.

International Monetary Fund (2012). The liberalization and management of capital flows: an institutional view. Washington, DC, 14 November.

International Monetary Fund (2013). Key Aspects of Macroprudential Policy. Washington, DC, 10 June.

Mehon R (2011). Waiting for the green light. The Banker, January.

Mills RH (1976). The regulation of short-term capital movements in major industrial countries. In: Swoboda AK, ed. Capital Movements and Their Control, A.W. Sijthoff: Leiden.

Tucker P (2013). The reform of international banking - some remaining challenges. Speech given by the Deputy Governor for Financial Stability of the Bank of England at the Oliver Wyman Institute Conference, 1 October.

WTO (2011). WTO Committee on Trade in Financial Services, "Unintended consequences of remedial measures taken to correct the global financial crisis: possible implications for WTO compliance". Communication from Barbados JOB/SERV/38. 18 February. 


\section{UNCTAD Discussion Papers}

\begin{tabular}{|c|c|c|c|}
\hline No. & Date & Author(s) & Title \\
\hline 215 & March 2014 & Stephany Griffith-Jones & A BRICS development bank: A dream coming true? \\
\hline 214 & December 2013 & Jörg Mayer & $\begin{array}{l}\text { Towards more balanced growth strategies in developing } \\
\text { countries: Issues related to market size, trade balances } \\
\text { and purchasing power }\end{array}$ \\
\hline 213 & November 2013 & Shigehisa Kasahara & $\begin{array}{l}\text { The Asian developmental State and the Flying Geese } \\
\text { paradigm }\end{array}$ \\
\hline 212 & November 2013 & $\begin{array}{l}\text { Vladimir Filimonov, } \\
\text { David Bicchetti, } \\
\text { Nicolas Maystre and } \\
\text { Didier Sornette }\end{array}$ & $\begin{array}{l}\text { Quantification of the high level of endogeneity and of } \\
\text { structural regime shifts in commodity markets }\end{array}$ \\
\hline 211 & October 2013 & $\begin{array}{l}\text { André Nassif, } \\
\text { Carmem Feijó and } \\
\text { Eliane Araújo }\end{array}$ & $\begin{array}{l}\text { Structural change and economic development: Is Brazil } \\
\text { catching up or falling behind? }\end{array}$ \\
\hline 210 & December 2012 & $\begin{array}{l}\text { Giovanni Andrea Cornia } \\
\text { and Bruno Martorano }\end{array}$ & $\begin{array}{l}\text { Development policies and income inequality in selected } \\
\text { developing regions, 1980-2010 }\end{array}$ \\
\hline 209 & November 2012 & $\begin{array}{l}\text { Alessandro Missale and } \\
\text { Emanuele Bacchiocchi }\end{array}$ & Multilateral indexed loans and debt sustainability \\
\hline 208 & October 2012 & $\begin{array}{l}\text { David Bicchetti and } \\
\text { Nicolas Maystre }\end{array}$ & $\begin{array}{l}\text { The synchronized and long-lasting structural change on } \\
\text { commodity markets: Evidence from high frequency data }\end{array}$ \\
\hline 207 & July 2012 & $\begin{array}{l}\text { Amelia U. Santos- } \\
\text { Paulino }\end{array}$ & $\begin{array}{l}\text { Trade, income distribution and poverty in developing } \\
\text { countries: A survey }\end{array}$ \\
\hline 206 & December 2011 & $\begin{array}{l}\text { André Nassif, } \\
\text { Carmem Feijó } \\
\text { and Eliane Araújo }\end{array}$ & $\begin{array}{l}\text { The long-term "optimal" real exchange rate and } \\
\text { the currency overvaluation trend in open emerging } \\
\text { economies: The case of Brazil }\end{array}$ \\
\hline 205 & December 2011 & Ulrich Hoffmann & $\begin{array}{l}\text { Some reflections on climate change, green growth } \\
\text { illusions and development space }\end{array}$ \\
\hline 204 & October 2011 & Peter Bofinger & The scope for foreign exchange market interventions \\
\hline 203 & September 2011 & $\begin{array}{l}\text { Javier Lindenboim, } \\
\text { Damián Kennedy and } \\
\text { Juan M. Graña }\end{array}$ & $\begin{array}{l}\text { Share of labour compensation and aggregate demand } \\
\text { discussions towards a growth strategy }\end{array}$ \\
\hline 202 & June 2011 & Pilar Fajarnes & $\begin{array}{l}\text { An overview of major sources of data and analyses } \\
\text { relating to physical fundamentals in international } \\
\text { commodity markets }\end{array}$ \\
\hline 201 & February 2011 & Ulrich Hoffmann & $\begin{array}{l}\text { Assuring food security in developing countries under the } \\
\text { challenges of climate change: Key trade and development } \\
\text { issues of a fundamental transformation of agriculture }\end{array}$ \\
\hline 200 & September 2010 & Jörg Mayer & Global rebalancing: Effects on trade flows and employment \\
\hline 199 & June 2010 & $\begin{array}{l}\text { Ugo Panizza, } \\
\text { Federico Sturzenegger } \\
\text { and Jeromin Zettelmeyer }\end{array}$ & International government debt \\
\hline 198 & April 2010 & $\begin{array}{l}\text { Lee C. Buchheit and } \\
\text { G. Mitu Gulati }\end{array}$ & Responsible sovereign lending and borrowing \\
\hline 197 & March 2010 & Christopher L. Gilbert & $\begin{array}{l}\text { Speculative influences on commodity futures prices } \\
2006-2008\end{array}$ \\
\hline 196 & November 2009 & Michael Herrmann & $\begin{array}{l}\text { Food security and agricultural development in times of } \\
\text { high commodity prices }\end{array}$ \\
\hline 195 & October 2009 & Jörg Mayer & $\begin{array}{l}\text { The growing interdependence between financial and } \\
\text { commodity markets }\end{array}$ \\
\hline
\end{tabular}




\begin{tabular}{|c|c|c|c|}
\hline No. & Date & Author(s) & Title \\
\hline 194 & June 2009 & Andrew Cornford & $\begin{array}{l}\text { Statistics for international trade in banking services: } \\
\text { Requirements, availability and prospects }\end{array}$ \\
\hline 193 & January 2009 & Sebastian Dullien & $\begin{array}{l}\text { Central banking, financial institutions and credit creation } \\
\text { in developing countries }\end{array}$ \\
\hline 192 & November 2008 & Enrique Cosio-Pascal & $\begin{array}{l}\text { The emerging of a multilateral forum for debt } \\
\text { restructuring: The Paris Club }\end{array}$ \\
\hline 191 & October 2008 & Jörg Mayer & Policy space: What, for what, and where? \\
\hline 190 & October 2008 & Martin Knoll & $\begin{array}{l}\text { Budget support: A reformed approach or old wine in new } \\
\text { skins? }\end{array}$ \\
\hline 189 & September 2008 & Martina Metzger & Regional cooperation and integration in sub-Saharan Africa \\
\hline 188 & March 2008 & Ugo Panizza & $\begin{array}{l}\text { Domestic and external public debt in developing } \\
\text { countries }\end{array}$ \\
\hline 187 & February 2008 & Michael Geiger & $\begin{array}{l}\text { Instruments of monetary policy in China and their } \\
\text { effectiveness: 1994-2006 }\end{array}$ \\
\hline 186 & January 2008 & Marwan Elkhoury & $\begin{array}{l}\text { Credit rating agencies and their potential impact on } \\
\text { developing countries }\end{array}$ \\
\hline 185 & July 2007 & Robert Howse & The concept of odious debt in public international law \\
\hline 184 & May 2007 & André Nassif & $\begin{array}{l}\text { National innovation system and macroeconomic policies: } \\
\text { Brazil and India in comparative perspective }\end{array}$ \\
\hline 183 & April 2007 & Irfan ul Haque & Rethinking industrial policy \\
\hline 182 & October 2006 & Robert Rowthorn & $\begin{array}{l}\text { The renaissance of China and India: implications for the } \\
\text { advanced economies }\end{array}$ \\
\hline 181 & October 2005 & Michael Sakbani & $\begin{array}{l}\text { A re-examination of the architecture of the international } \\
\text { economic system in a global setting: Issues and proposals }\end{array}$ \\
\hline 180 & October 2005 & $\begin{array}{l}\text { Jörg Mayer and } \\
\text { Pilar Fajarnes }\end{array}$ & Tripling Africa’s Primary Exports: What? How? Where? \\
\hline 179 & April 2005 & S.M. Shafaeddin & $\begin{array}{l}\text { Trade liberalization and economic reform in developing } \\
\text { countries: structural change or de-industrialization? }\end{array}$ \\
\hline 178 & April 2005 & Andrew Cornford & Basel II: The revised framework of June 2004 \\
\hline 177 & April 2005 & Benu Schneider & $\begin{array}{l}\text { Do global standards and codes prevent financial crises? } \\
\text { Some proposals on modifying the standards-based approach }\end{array}$ \\
\hline 176 & December 2004 & Jörg Mayer & $\begin{array}{l}\text { Not totally naked: Textiles and clothing trade in a quota } \\
\text { free environment }\end{array}$ \\
\hline 175 & August 2004 & S.M. Shafaeddin & $\begin{array}{l}\text { Who is the master? Who is the servant? Market or } \\
\text { Government? }\end{array}$ \\
\hline 174 & August 2004 & Jörg Mayer & $\begin{array}{l}\text { Industrialization in developing countries: Some evidence } \\
\text { from a new economic geography perspective }\end{array}$ \\
\hline 173 & June 2004 & Irfan ul Haque & Globalization, neoliberalism and labour \\
\hline 172 & June 2004 & Andrew J. Cornford & $\begin{array}{l}\text { The WTO negotiations on financial services: Current } \\
\text { issues and future directions }\end{array}$ \\
\hline 171 & May 2004 & Andrew J. Cornford & Variable geometry for the WTO: Concepts and precedents \\
\hline 170 & May 2004 & $\begin{array}{l}\text { Robert Rowthorn and } \\
\text { Ken Coutts }\end{array}$ & $\begin{array}{l}\text { De-industrialization and the balance of payments in } \\
\text { advanced economies }\end{array}$ \\
\hline 169 & April 2004 & Shigehisa Kasahara & $\begin{array}{l}\text { The flying geese paradigm: A critical study of its } \\
\text { application to East Asian regional development }\end{array}$ \\
\hline 168 & February 2004 & Alberto Gabriele & $\begin{array}{l}\text { Policy alternatives in reforming power utilities in } \\
\text { developing countries: A critical survey }\end{array}$ \\
\hline 167 & January 2004 & $\begin{array}{l}\text { Richard Kozul-Wright } \\
\text { and Paul Rayment }\end{array}$ & Globalization reloaded: An UNCTAD Perspective \\
\hline
\end{tabular}




\begin{tabular}{|c|c|c|c|}
\hline No. & Date & Author(s) & Title \\
\hline 166 & February 2003 & Jörg Mayer & The fallacy of composition: A review of the literature \\
\hline 165 & November 2002 & Yuefen Li & China's accession to WTO: Exaggerated fears? \\
\hline 164 & November 2002 & $\begin{array}{l}\text { Lucas Assuncao and } \\
\text { ZhongXiang Zhang }\end{array}$ & Domestic climate change policies and the WTO \\
\hline 163 & November 2002 & A.S. Bhalla and S. Qiu & $\begin{array}{l}\text { China's WTO accession. Its impact on Chinese } \\
\text { employment }\end{array}$ \\
\hline 162 & July 2002 & $\begin{array}{l}\text { Peter Nolan and } \\
\text { Jin Zhang }\end{array}$ & The challenge of globalization for large Chinese firms \\
\hline 161 & June 2002 & $\begin{array}{l}\text { Zheng Zhihai and } \\
\text { Zhao Yumin }\end{array}$ & China's terms of trade in manufactures, 1993-2000 \\
\hline 160 & June 2002 & S.M. Shafaeddin & $\begin{array}{l}\text { The impact of China's accession to WTO on exports of } \\
\text { developing countries }\end{array}$ \\
\hline 159 & May 2002 & $\begin{array}{l}\text { Jörg Mayer, } \\
\text { Arunas Butkevicius and } \\
\text { Ali Kadri }\end{array}$ & Dynamic products in world exports \\
\hline 158 & April 2002 & $\begin{array}{l}\text { Yilmaz Akyüz and } \\
\text { Korkut Boratav }\end{array}$ & The making of the Turkish financial crisis \\
\hline 157 & September 2001 & Heiner Flassbeck & The exchange rate: Economic policy tool or market price? \\
\hline 156 & August 2001 & Andrew J. Cornford & $\begin{array}{l}\text { The Basel Committee's proposals for revised capital } \\
\text { standards: Mark } 2 \text { and the state of play }\end{array}$ \\
\hline 155 & August 2001 & Alberto Gabriele & $\begin{array}{l}\text { Science and technology policies, industrial reform and } \\
\text { technical progress in China: Can socialist property rights } \\
\text { be compatible with technological catching up? }\end{array}$ \\
\hline 154 & June 2001 & Jörg Mayer & $\begin{array}{l}\text { Technology diffusion, human capital and economic } \\
\text { growth in developing countries }\end{array}$ \\
\hline 153 & December 2000 & Mehdi Shafaeddin & $\begin{array}{l}\text { Free trade or fair trade? Fallacies surrounding the theories } \\
\text { of trade liberalization and protection and contradictions in } \\
\text { international trade rules }\end{array}$ \\
\hline 152 & December 2000 & Dilip K. Das & Asian crisis: Distilling critical lessons \\
\hline 151 & October 2000 & Bernard Shull & $\begin{array}{l}\text { Financial modernization legislation in the United States - } \\
\text { Background and implications }\end{array}$ \\
\hline 150 & August 2000 & Jörg Mayer & $\begin{array}{l}\text { Globalization, technology transfer and skill accumulation } \\
\text { in low-income countries }\end{array}$ \\
\hline 149 & July 2000 & Mehdi Shafaeddin & $\begin{array}{l}\text { What did Frederick List actually say? Some clarifications } \\
\text { on the infant industry argument }\end{array}$ \\
\hline 148 & April 2000 & Y1lmaz Akyüz & $\begin{array}{l}\text { The debate on the international financial architecture: } \\
\text { Reforming the reformers }\end{array}$ \\
\hline 147 & April 2000 & Martin Khor & Globalization and the South: Some critical issues \\
\hline 146 & February 2000 & $\begin{array}{l}\text { Manuel R. Agosin and } \\
\text { Ricardo Mayer }\end{array}$ & $\begin{array}{l}\text { Foreign investment in developing countries: Does it } \\
\text { crowd in domestic investment? }\end{array}$ \\
\hline 145 & January 2000 & $\begin{array}{l}\text { B. Andersen, } \\
\text { Z. Kozul-Wright and } \\
\text { R. Kozul-Wright }\end{array}$ & $\begin{array}{l}\text { Copyrights, competition and development: The case of } \\
\text { the music industry }\end{array}$ \\
\hline
\end{tabular}

Copies of UNCTAD Discussion Papers may be obtained from the Publications Assistant, Macroeconomic and Development Policies Branch (MDPB), Division on Globalization and Development Strategies (DGDS), United Nations Conference on Trade and Development (UNCTAD), Palais des Nations, CH-1211 Geneva 10, Switzerland; e-mail: gdsinfo@unctad.org; fax no: +41 229170274.

UNCTAD Discussion Papers are accessible on the website at http://unctad.org. 